IZA DP No. 8399

Deriving the New Quantity Equation:

An Approach for a Closed and an Open Economy

Paul J.J. Welfens

August 2014 


\title{
Deriving the New Quantity Equation: An Approach for a Closed and an Open Economy
}

\author{
Paul J.J. Welfens \\ EIIW and Schumpeter School, University of Wuppertal, \\ Sciences Po, IZA and AICGS/Johns Hopkins University
}

\section{Discussion Paper No. 8399 \\ August 2014}

\author{
IZA \\ P.O. Box 7240 \\ 53072 Bonn \\ Germany \\ Phone: +49-228-3894-0 \\ Fax: +49-228-3894-180 \\ E-mail: iza@iza.org
}

Any opinions expressed here are those of the author(s) and not those of IZA. Research published in this series may include views on policy, but the institute itself takes no institutional policy positions. The IZA research network is committed to the IZA Guiding Principles of Research Integrity.

The Institute for the Study of Labor (IZA) in Bonn is a local and virtual international research center and a place of communication between science, politics and business. IZA is an independent nonprofit organization supported by Deutsche Post Foundation. The center is associated with the University of Bonn and offers a stimulating research environment through its international network, workshops and conferences, data service, project support, research visits and doctoral program. IZA engages in (i) original and internationally competitive research in all fields of labor economics, (ii) development of policy concepts, and (iii) dissemination of research results and concepts to the interested public.

IZA Discussion Papers often represent preliminary work and are circulated to encourage discussion. Citation of such a paper should account for its provisional character. A revised version may be available directly from the author. 
IZA Discussion Paper No. 8399

August 2014

\section{ABSTRACT \\ Deriving the New Quantity Equation: An Approach for a Closed and an Open Economy ${ }^{*}$}

This theoretical contribution shows a simple way in which the quantity equation can be derived as a long-term equilibrium solution for the case of a closed economy and an open economy, respectively. It is shown first for the case of a closed economy which parameters stand behind "velocity" and that indeed there are arguments why velocity should be constant over time - assuming a specific parameter set of the goods market. It is noteworthy that the quantity equation can be derived both in a demand-side context and in a long run supply-side approach. Moreover, a new derivation is presented for the case of an open economy and it is shown that trade as well as foreign direct investment should be expected to have an influence on the price level and the inflation rate, respectively. Finally, the analysis suggests that financial market activities should have an impact on the price level.

JEL Classification: E00, F41, E50, E52, H20

Keywords: macroeconomics, open economy, quantity equation, monetary policy, tax policy

Corresponding author:

Paul J.J. Welfens

University of Wuppertal

Rainer-Gruenter-Str. 21

42119 Wuppertal

Germany

E-mail:welfens@wiwi.uni-wuppertal.de

I gratefully acknowledge technical support by Murat Ismail and David Hanrahan. Moreover I appreciate discussions with Jens Perret (Schumpeter School of Business and Economics) and Thomas Gries, University of Paderborn. The usual disclaimer applies. 


\section{Table of contents}

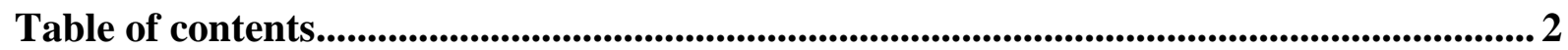

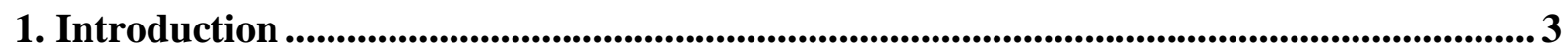

2. Theoretical Analysis: Deriving the Quantity Equation ......................................................4

2.1 Role of the Stock Market................................................................................... 8

2.2 Open Economy with Trade and Foreign Direct Investment ....................................... 9

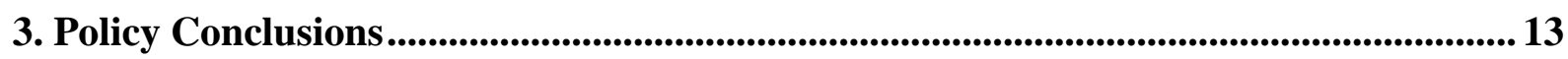

Appendix: Supply-side View on the Quantity Equation: Simple Monetary Growth

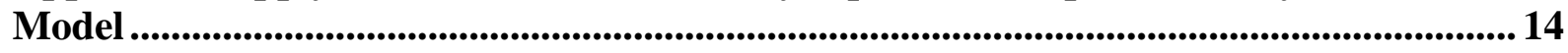

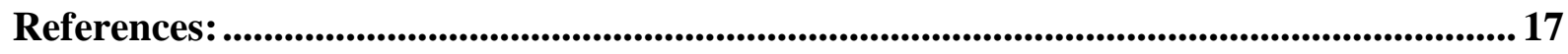




\section{Introduction}

The quantity equation is a famous theoretical approach dating back to Irving Fisher (1911). It has enjoyed a prominent role in the monetarist debate where Milton Friedman (1968) has emphasized this equation in several contributions. The equation states that in a monetary economy there is a relationship between the stock of money $(\mathrm{M})$, the price level $(\mathrm{P})$, velocity (V) and real output (Y):

$$
\mathrm{MV}=\mathrm{PY}
$$

One view to interprete this equation is to consider MV to reflect aggregate nominal (long term) demand, an alternative interpretation is to consider the quantity equation as an implicit money market equilibrium condition where the subsequent equation shows on the right-hand side the nominal demand for money:

$$
\mathrm{M}=\mathrm{V}^{\prime}(\ldots) \mathrm{PY}
$$

Here $V^{\prime}$ is the inverse of $\mathrm{V}$, and $\mathrm{V}^{\prime}$ is assumed to be a negative function of the nominal interest rate (hence $\mathrm{V}$ is a positive function of the interest rate) which is assumed to be composed of the sum of the real interest rate $r$ and the expected inflation rate $\pi^{\mathrm{E}}$. Often it has been assumed in the monetary debate - in contrast to KEYNES (1936) - that velocity V is constant and, therefore, the growth rate of the money supply minus the growth rate of output is then equal to the inflation rate $\mathrm{d} \ln \mathrm{P} / \mathrm{dt}$. However, what is missing is a derivation of the quantity equation; the simple argument that transaction demand is proportionate to nominal output is only one possible approach. In the following analysis the quantity equation is derived in a new way for both the case of a closed economy and the case of an open economy. As it can be shown that $\mathrm{V}$ is actually composed of several parameters related to components of aggregate demand, one gets a better idea about the nature of the variable V; and possibly als why $\mathrm{V}$ is declining over time in industrialized countries.

It is shown at first for the case of a closed economy which parameters stand behind "velocity" and that there are indeed arguments why velocity should be constant over time - under very specific conditions. Moreover, a similar derivation is shown for the case of an open economy and it is shown that trade, as well as foreign direct investment, should be expected to have an influence on the price level and the inflation rate, respectively. Finally, the analysis suggests that financial market activities should have an impact on the price level: The larger the real stock market price is, the lower the equilibrium price level will be, so that a structural boom in the stock market - raising the level of the stock market price index relative to the output price level - will go along with a dampening effect on the price level. 


\section{Theoretical Analysis: Deriving the Quantity Equation}

Given standard microeconomic analysis it is natural to set up an explanation for the price level development on the basis of the excess demand in the aggregate goods market. How will demand expansion affect the price level dynamics? It is assumed for simplicity that aggregate supply $\mathrm{Y}$ is demand driven or exogenous so that we, with $\lambda$ as a positive parameter (and $\mathrm{t}$ denoting the time index), have:

$$
(d P / d t)=\lambda\left(Y^{d}-Y\right) P
$$

Thus the aggregate nominal excess demand determines $\mathrm{dP} / \mathrm{dt}$; in traditional approaches the real excess demand is considered. Aggregate real demand is $\mathrm{Y}^{\mathrm{d}}$ and in a closed economy it is the sum of real consumption $\mathrm{C}$, real investment I and real government consumption $\mathrm{G}$; for the sake of simplicity it will be assumed that $G=\gamma Y$ and that net investment $I^{\text {net }}=v^{\prime} Y\left(v^{\prime}>0\right)$. By assumption there is no depreciation of capital. It is assumed that consumption is proportionate to disposable income $\mathrm{Y}(1-\tau)$ where $\tau$ is the income tax rate; moreover $\mathrm{C}$ is proportionate to the stock of real money $\mathrm{M} / \mathrm{P}$ so that $\mathrm{C}=\mathrm{c}(1-\tau) \mathrm{Y}+\mathrm{c}^{\prime} \mathrm{M} / \mathrm{P}\left(0<\mathrm{c}<1 ; \mathrm{c}^{\prime}>0\right)$. In a nutshell M/P stands for wealth of private households. Thus, aggregate demand can be written as:

(4) $Y^{d}=c(1-\tau) Y+c^{\prime} M / P+v^{\prime} Y+\gamma Y$

The price adjustment equation therefore reads in a perfect foresight setting:

$$
(d P / d t) / P=\lambda\left(c(1-\tau) Y+c^{\prime} M / P+v^{\prime} Y+\gamma Y-Y\right)
$$

Multiplying by $\mathrm{P}$ and rearranging gives:

$$
\mathrm{dP} / \mathrm{dt}+\lambda\left(1-\mathrm{c}(1-\tau)-\mathrm{v}^{\prime}-\gamma\right) \mathrm{YP}=\lambda \mathrm{c}^{\prime} \mathrm{M}
$$

It is assumed that $\left(1-\mathrm{c}(1-\tau)-\mathrm{v}^{\prime}-\gamma\right)$ is positive; if it were negative the price level would increase all the time since the solution of a simple differential equation $\mathrm{dx} / \mathrm{dt}+\mathrm{a}^{\prime} \mathrm{x}=\mathrm{b}^{\prime}$ is $\mathrm{x}(\mathrm{t})$ $=C^{\prime} e^{-a^{\prime} t}+b^{\prime} / a$ ' where a' and b' are positive parameters while $C^{\prime}$ is determined from the original conditions (time index is $\mathrm{t}$ and initially $\mathrm{t}=0$; $\mathrm{e}^{\prime}$ is the Euler number); the long term solution $\mathrm{x} \#$ therefore is $\mathrm{b}^{\prime} / \mathrm{a}$ '.

Denoting the steady state value by $\mathrm{P} \#$ the solution for $\mathrm{P}(\mathrm{t})$ is given by (with $\mathrm{C}^{\prime}$ to be determined from the initial equilibrium in $\mathrm{t}=0$ ):

$$
\mathrm{P}(\mathrm{t})=\mathrm{C}^{\prime} \mathrm{e}^{\prime-\lambda\left(1-\mathrm{c}(1-\tau)-\mathrm{v}^{\prime}-\gamma\right) \mathrm{Yt}}+\mathrm{P \#}
$$


The long-term equilibrium price level (with the time index $t$ approaching infinity) thus is:

$$
\mathrm{P} \#=\mathrm{c}^{\prime} \mathrm{M} /\left[\left(1-\mathrm{c}(1-\tau)-\mathrm{v}^{\prime}-\gamma\right) \mathrm{Y}\right]=\mathrm{VM} / \mathrm{Y}
$$

Note that P\# is a long-term solution for the price level dynamics of the economy considered. The long run comparative statics are fully in line with the quantity equation and indeed we have:

$$
\mathrm{V}=\mathrm{c}^{\prime} /\left(1-\mathrm{c}(1-\tau)-\mathrm{v}^{\prime}-\gamma\right)
$$

From equation (8) it follows after taking logs - while assuming that $c(1-\tau)-v^{\prime}-\gamma$ is close to zero - and taking the time derivative that

(8') $\mathrm{d} \operatorname{lnP\# /dt}=\mathrm{d} \ln (\mathrm{M} / \mathrm{P}) / \mathrm{dt}-\mathrm{d} \ln \mathrm{Y} / \mathrm{dt}+(1-\tau) \mathrm{dc} / \mathrm{dt}-\mathrm{cd} \tau / \mathrm{dt}+\mathrm{dv} \mathrm{v}^{\prime} / \mathrm{dt}+\mathrm{d} \gamma / \mathrm{dt}$

A rise of the income tax rate will reduce the steady state price level and the respective semielasticity is less than unity (if $0<c<1$ ). In an enhanced setup on could consider the impact of the income tax rate on output and the growth rate of $\mathrm{Y}$, respectively.

The short-term and medium-term adjustment dynamics could indeed bring additional insights; with respect to the parameter $\lambda$ one might assume that it is a positive function of $\left(\mathrm{c}+\mathrm{v}^{\prime}\right) / \gamma$, namely under the assumption that the private sectors' transactions take place in a more price responsive environment than government consumption: This points to empirical questions not considered here. An alternative specification of the price level equation might be explored: As regards the basic price level adjustment equation (3) it might be adequate to use instead

$$
(\mathrm{dP} / \mathrm{dt})=\lambda\left[\left(\mathrm{Y}^{\mathrm{d}}-\mathrm{Y}\right) / \mathrm{Y}\right] \mathrm{P}=\lambda\left[\left(\mathrm{Y}^{\mathrm{d}} / \mathrm{Y}-1\right)\right] \mathrm{P}=\lambda[(\mathrm{Y} \#(1-\mathrm{h} \text { "u })-1)] \mathrm{P}
$$

This would bring a change for the interim adjustment dynamics where it has been assumed that $\mathrm{Y}^{\mathrm{d}} / \mathrm{Y}$ in turn is the capacity utilization; $\mathrm{Y} \#$ is long run equilibrium income that can be derived from a production function $\mathrm{Y}=(\mathrm{M} / \mathrm{P})^{\beta^{\prime}} \mathrm{K}^{\beta}(\mathrm{AL})^{1-\beta-\beta^{\prime}}$ and (with $\tau$ denoting the income tax rate) a savings function $S=s(1-\tau) Y$; knowledge $A$ and population $L$ are given (one can define $\left.\mathrm{k}^{\prime}:=\mathrm{K} /(\mathrm{AL}) ; \mathrm{y}^{\prime}:=\mathrm{Y} /(\mathrm{AL}) ; \mathrm{m}^{\prime}:=\mathrm{M} /(\mathrm{AL})\right)$, the rate of capital depreciation is $\delta$ and the goods market equilibrium condition is $S=d K / d t+\delta K$ (WELFENS, 2011); the assumption behind this production function is that real money balances enter the production function as a positive external effect of households' holdings of real money balances (it should be notet that assuming that central banks adopts a policy $(\mathrm{M} / \mathrm{P}) /(\mathrm{AL})=\mu$ " - where $\mu ">0$ - the steady state solution for output relative to labor in efficiency units $\mathrm{y}^{\prime} \#$ then is given by the expression $y^{\prime} \#=m^{, \beta^{\prime} /(1-\beta)}(s(1-\tau) / \delta)^{\beta /(1-\beta)}$; this expression shows that in the specific case of $\beta^{\prime}=(1-\beta)$ there 
is supply-side quantitiy equation that is derived from a monetary growth model and that output relative to efficiency units can be decomposed in the standard term from the Solow model and the term $m^{, \beta^{\prime} /(1-\beta)}$ (for details see appentdix). The implication of the money supply rule in a modified setup with a given $\mathrm{L}$ and an exogenous growth rate of knowledge (a; thus a will be equal to output growth in the steady state) is that the inflation rate will be equal to the growth rate of money supply growth rate minus the growth rate of output while (M/P)/(AL) is a determinant of the level of the growth path).

Capacity utilization can be linked to the unemployment rate $\mathrm{u}$ (h" standing for a positive parameter); the higher capacity utilization, the lower the unemployment rate will be. This does imply an indirect link to the Phillips curve in a specific form, in the context of inflationary expectations the link will be somewhat different - as implied by the subsequent inflation adjustment equation. As soon as there are positive inflation expectations one may argue that the relevant adjustment dynamics in goods markets are determined rather by an equation for the inflation rate $\pi$ (note $0<\beta$ " $<1$ ) which basically can be written (with $\mu$ denoting the growth rate of the money supply) as:

$$
\mathrm{d} \pi / \mathrm{dt}=(\mu-\mathrm{a}) \pi^{\beta^{\prime \prime}}-\Omega^{\prime} \pi
$$

$$
\pi \#=\left((\mu-a) / \Omega^{\prime}\right)^{1 /\left(1-\beta^{\prime \prime}\right)}
$$

The mechanics and basic arguments presented here for price level adjustment are not much different from what is relevant in an inflation context; except for the special problem of bracket creep which means that taxation is artificially reinforced by inflation (unless government uses income tables that are fully indexed with respect to the price level).

In the subsequent analysis the focus is on an economy with an expected zero inflation rate and the focus indeed is on the price level dynamics. From a policy perspective V is constant - for given parameters; but $\mathrm{V}$ is a negative function of the income tax rate $\tau$; an aspect which has been neglected in traditional analysis. Indeed, so far no analytical link has been made between velocity $\mathrm{V}$ and the goods market except for authors referring to transaction technology. $\mathrm{V}$ is also a positive function of the government expenditure parameter $\gamma$ and the marginal consumption ratios c and c' respectively; and the investment parameter v'.

Referring to standard insights from empirical analysis: Does the nominal interest rate play a role for velocity? Consider an economy in which there is government debt and hence interest income accruing to households is $\mathrm{Y}+\mathrm{iB} / \mathrm{P}$ ( $\mathrm{B}$ is nominal short-term government debt and non-indexed bonds, respectively); government has to pay a nominal interest rate that will exceed the real interest rate $r$ in the case of inflation, since inflation erodes the present value of the principal paid at the end of maturity. Assume that government has a target ratio $(\mathrm{B} / \mathrm{P}) / \mathrm{Y}$ $=\theta$ so that $\mathrm{B} / \mathrm{P}=\theta \mathrm{Y}$. Thus, the modified consumption function can now be written as

$$
\mathrm{C}=\mathrm{c}(1+\mathrm{i} \theta)(1-\tau) \mathrm{Y}+\mathrm{c}^{\prime} \mathrm{M} / \mathrm{P}
$$


In an economy with zero expected inflation the nominal interest rate $i$ has, of course, to be replaced by $r$. It is noteworthy that a long-term perspective for the consumption function would suggest to modify the equation along the sense of Friedman's permanent income (Friedman, 1968) or Welfens (2011) who has suggested to use a specific concept of permanent income which is a linear combination of current income and the steady state income as obtained from a growth model; a simple way to switch to a more long-term perspective would be to assume that households expect the current income to continue in the future so that one may specific the consumption function as $C=c(1+i \theta)(1-\tau) \mathrm{Y} / \mathrm{r}+\mathrm{c}^{\prime} \mathrm{M} / \mathrm{P}$. With a given real interest rate the permanent gross income simply is $\mathrm{Y} / \mathrm{r}$, but no crucial additional insights are gained from this for our price level analysis; however, one should notice that profit maximization for the case of a Cobb-Douglas production function (in a setup with no capital depreciation; $\beta$ is the output elasticity of capital) implies $\beta Y / K=r$ and hence $\mathrm{Y} / \mathrm{r}$ can be replaced by $\mathrm{K} / \mathrm{B}$ : In such a modified setup the long run consumption function is, thus, completely determined by asset stocks, not by current income:

$$
\mathrm{C}=[\mathrm{c}(1+\mathrm{i} \theta)(1-\tau) / \beta] \mathrm{K}+\mathrm{c}^{\prime} \mathrm{M} / \mathrm{P} .
$$

Furthermore, let us consider the direct role of expected inflation in consumption. If households anticipate inflation - hence the expected inflation rate is positive -, current consumption will be reduced in an imperfect taxation system and with workers' uncertainty about future wage income dynamics. Now the consumption demand $C$ is modified to read: $C=$ $c(1+i \theta)(1-\tau) Y+c^{\prime}(M / P)-h^{\prime} \pi^{E}(1-\beta) Y$ where $h$ is a positive parameter and $(1-\beta) Y$ is labor income $\left(0<\beta<1\right.$; one may assume a macroeconomic production function $Y=K^{\beta} L^{1-\beta}$ where $K$ is the capital stock and $\mathrm{L}$ is labor input. Thus, workers are assumed to reduce real consumption as a consequence of anticipated inflation, possibly due to either anticipated bracket creep problems or because the anticipated future nominal wage increases are below the inflation rate.

$$
\begin{aligned}
& \mathrm{V}=\mathrm{c}^{\prime} /\left[\left(1-\mathrm{c}(1+\mathrm{i} \theta)(1-\tau)-\mathrm{h}^{\prime} \pi^{\mathrm{E}}(1-\beta)-\mathrm{v}^{\prime}-\gamma\right)\right] \\
& \mathrm{V}=\mathrm{c}^{\prime} /\left[\left(1-\mathrm{c}(1-\tau)-\operatorname{ci} \theta(1-\tau)-\mathrm{h}^{\prime} \pi^{\mathrm{E}}(1-\beta)-\mathrm{v}^{\prime}-\gamma\right)\right]
\end{aligned}
$$

Thus, $\mathrm{V}$ is a positive function of the nominal interest rate and the expected inflation, respectively. Since $i=r+\pi^{E}$ the expected inflation rate enters $V$ twice. It is well known that velocity is declining in the long run in the US and other OECD countries. Looking at the above equation, a rise of the income tax rate or a decline of the investment-GDP ratio could explain the long term increase of $\mathrm{V}$. The ratio of nominal investment to nominal GDP has declined in many industrialized countries and NICs due to the fact information \& communication technology investment - here absolute prices are declining over time - has played an increasing role in total investment over time (Welfens/Perret, 2014). 


\subsection{Role of the Stock Market}

If one wants to consider the role of the stock market one will take into consideration the role of the real value of stocks (its number is equal to the number of capital units $\mathrm{K}$ ), namely $\mathrm{P}^{\prime} \mathrm{K} / \mathrm{P}$ where $\mathrm{P}^{\prime}$ is the stock market price index. The new consumption function reads $\mathrm{C}=\mathrm{c}(1-$ $\tau) \mathrm{Y}+\mathrm{c}^{\prime} \mathrm{M} / \mathrm{P}+\mathrm{c}^{\prime \prime} \mathrm{P}$ 'K/P. If the last two terms are reflecting the impact of real wealth $\mathrm{A}^{\prime}=\mathrm{M} / \mathrm{P}$ + P'K/P we can replace c" by c'. Government bonds are not included here because of the assumption of full Ricardian equivalence. However, there is no problem to include (shortterm) bonds. The general definition of wealth - with a parameter $\phi$ for the intensity of Ricardian equivalence is given by:

(16) $\mathrm{A}^{\prime}=\mathrm{M} / \mathrm{P}+\mathrm{P}^{\prime} \mathrm{K} / \mathrm{P}+\phi \mathrm{B} / \mathrm{P}$

Note, $\phi$ is in the range between 0 , which is full Ricardian equivalence, and 1, which is zero equivalence; the more open the economy is, the larger $\phi$ should be - in an open economy with free trade, capital flows and international labor mobility, there will be relatively numerous opportunities to escape taxation in the home country for a least part of life time of the respective consumer. With full Ricardian equivalence we get the steady state solution for the price level:

$$
\mathrm{P} \#=\left(c^{\prime} \mathrm{M}+\mathrm{c}^{\prime} \mathrm{P}^{\prime} \mathrm{K}\right) /\left[\left(1-\mathrm{c}(1-\tau)-\mathrm{i} \theta(1-\tau)-\mathrm{h} \pi^{\mathrm{E}}(1-\beta)-\mathrm{v}^{\prime}-\gamma\right) \mathrm{Y}\right]
$$

Assume that portfolio investors have a desired ratio $\Omega$ referring to the ratio of the nominal value of stocks to the stock of money. If $\mathrm{P}^{\prime} \mathrm{K}=\Omega \mathrm{M}$, we can write

$$
\mathrm{P} \#=\mathrm{c}^{\prime}(1+\Omega)(\mathrm{M} / \mathrm{Y}) /\left(1-\mathrm{c}(1-\tau)-\mathrm{i} \theta(1-\tau)-\mathrm{h} \pi^{\mathrm{E}}(1-\beta)-\mathrm{v}^{\prime}-\gamma\right)
$$

Hence, we now have $\mathrm{V}$ as the parameter expression; government has an impact on the parameters $\tau$ and $\gamma$, while the ratio $\theta$ (debt to GDP) is endogenous so that one will have to consider that portfolio investor behavior implies that $r$ is a positive function of $\theta$. V can be summarized as:

$$
\mathrm{V}=\mathrm{c}^{\prime}(1+\Omega) /\left(1-\mathrm{c}(1-\tau)-\mathrm{i} \theta(1-\tau)-\mathrm{h} \pi^{\mathrm{E}}(1-\beta)-\mathrm{v}^{\prime}-\gamma\right)
$$

If the ratio $\mathrm{P}$ 'K/M is falling over time, the equilibrium price level will reduce. In a portfolio perspective the desired holding of $\mathrm{M}$ relative to $\mathrm{P}^{\prime} \mathrm{K}$ or relative to $\mathrm{Y}$ is a negative function of the interest rate and the expected inflation rate, respectively. Thus, in an inflationary economy the desired ratio $\Omega$ is rising so that the equilibrium price level increase will be higher than the percentage increase of $\mathrm{M}$ itself implies. Again, it is noteworthy that the short-term and 
medium-term adjustment dynamics can be quite different from the steady state solution and the respective implications of parameter analysis for that solution.

As regards the role of stock markets and capital accumulation, respectively, there could be a counter-effect to be considered within a modified quantity equation, and in the context of a CES function, which no longer implies fixed income shares of capital and labor, respectively. The above equation has suggested that the rise of the stock market price will raise $\mathrm{P \# ,} \mathrm{but} \mathrm{a}$ counter-effect will occur if output $\mathrm{Y}$ is a function of capital, labor and knowledge (A) where A is a positive function of the ratio of capital to output; this will be the case if there is a strong role of capital embodied technological progress. PIKETTY (2014) has emphasized that the ratio of capital to output has increased over time in the 19th century (with land playing a strong role) while it has reduced during the two world wars and the interwar period, after World War II it has increased again. Besides endogenous technological progress an autonomous progress component could also play a role. Here there is space for future additional research.

\subsection{Open Economy with Trade and Foreign Direct Investment}

Let us consider an economy which has inward FDI and trade, but for simplicity there are no FDI outflows - at least at first: in the most simple specification. What the impact of FDI globalization is, can indeed be understood by first looking at an asymmetric FDI model and then at a symmetric model with both FDI inflows and outflows. It will be argued that FDI inflows negatively affect aggregate demand (as long as exports do not strongly react to profits accruing from subsidiaries to parent companies abroad), but positively affect the production potential so that the steady state price level is reduced by FDI inflows. If, however, there is two-way FDI the impact is less clear. One could also look at the impact of FDI and the presence of multinational companies on the adjustment speed ( $\lambda$ and $\lambda$ ', respectively). The share of foreign investment in the capital stock of Country I is denoted by $\alpha^{*}$. It is assumed that consumption is proportionate to real national income $\mathrm{Z}=\mathrm{Y}\left(1-\alpha^{*} \beta\right)$, namely under the assumption that there is a production function $Y=K^{\beta}(A L)^{1-\beta}-$ with A denoting knowledge and that there is competition in goods and labor markets so that the share of capital income is B. Ignoring the role of stocks the consumption function for the case of asymmetric FDI is given by

$$
\mathrm{C}=\mathrm{c}(1-\tau) \mathrm{Z}+\mathrm{c}^{\prime} \mathrm{M} / \mathrm{P}
$$

It is assumed that the presence of subsidiaries from abroad raises the level of knowledge (Ao is the initial level of knowledge; $v$ " is a positive parameter):

$$
\mathrm{A}=\mathrm{A}_{0}\left(1+\mathrm{v} " \alpha^{*}\right)
$$


It is assumed that effective output is composed of a demand effect for Y (effective output is a hybrid result of demand effects plus supply effects) plus an additional foreign supply effect related to knowledge transfer. Thus the effective supply of output is given by:

$$
Y^{s}=Y\left(1+v^{\prime \prime} \alpha *\right)^{1-\beta}
$$

Hence supply, in logarithmic terms, is given by the approximation $\ln Y+(1-\beta) v^{\text {" }} \alpha^{*}$; it has been assumed that $\mathrm{v}^{\prime \prime} \alpha^{*}$ is close to zero so that $\ln (1+\mathrm{x}) \approx \mathrm{x}$ can be used.

Aggregate demand in this combined FDI and trade approach will be carefully defined here. The following case of assymetric FDI - only inflows into Country I (home country) - is based on the assumption that part of profits of subsidiaries is reinvested (positive parameter v" and that $x ">0$ expresses the impact of subsidiaries on market access in the source country of FDI, namely Country II), that exports are proportionate to $Z^{*}$ and that import is proportionate to national income $\mathrm{Z}$ while the elasticity of import with respect to the real exchange rate $\mathrm{q}^{*}:=\mathrm{eP}^{*} / \mathrm{P}$ is minus 1 ; the export function is specified in a rather pragmatic way, namely $\mathrm{X}=$ $\mathrm{x}\left(1+\mathrm{x}^{\prime} \alpha^{*}\right) \mathrm{Z}^{*} / \mathrm{q}^{*}=\mathrm{x}\left(1+\mathrm{x}^{\prime} \alpha^{*}\right)\left(\mathrm{Y}^{*}+\alpha^{*} \beta \mathrm{Y} / \mathrm{q}^{*}\right) \mathrm{q}^{*}$ so that the elasticity with respect to $\mathrm{q}^{*}$ is unity while $Z^{*}=\left(\mathrm{Y}^{*}+\alpha^{*} \beta \mathrm{Y} / \mathrm{q}^{*}\right)$.

$$
Y^{d}=c(1-\tau)\left(1-\alpha^{*} \beta\right) Y+c^{\prime} M / P+v^{\prime}\left(1+v^{\prime \prime} \alpha^{*} \beta\right) Y+\gamma Y+x\left(1+x^{\prime} \alpha^{*}\right)\left(Y^{*} q^{*}+\alpha^{*} \beta Y\right)-j\left(1-\alpha^{*} \beta\right) Y
$$

Note that $\mathrm{e}$ is the nominal exchange rate in price notation and that a flexible exchange rate system is considered. Next, let us consider the adjustment equation for the price level in Country I (home country): Here the role of outward foreign investment (as proxied by the parameter $\alpha^{*}$ ) is assumed to affect the adjustment speed where the relevant parameter $\lambda$ " can be positive or negative.

$$
\mathrm{dP} / \mathrm{dt}=\lambda\left(1+\lambda^{\prime \prime} \alpha^{*}\right)\left(\mathrm{Y}^{\mathrm{d}}-\mathrm{Y}\right) \mathrm{P}=\lambda\left(1+\lambda^{\prime \prime} \alpha^{*}\right)\left[\mathrm{c}(1-\tau)\left(1-\alpha^{*} \beta\right) \mathrm{Y}+\mathrm{c}^{\prime} \mathrm{M} / \mathrm{P}+\mathrm{v}^{\prime}\left(1+\mathrm{v}^{\prime \prime} \alpha^{*} \beta\right) \mathrm{Y}\right.
$$

$\left.+\gamma Y+x\left(1+x^{\prime} \alpha^{*}\right)\left(Y^{*} q^{*}+\alpha^{*} \beta Y\right)-j\left(1-\alpha^{*} \beta\right) Y-Y\right] P$

The steady state price level P\# is given by:

$$
\mathrm{P \#}=\left[\left(\mathrm{c}^{\prime}+\mathrm{x}\left(1+\mathrm{x}^{\prime} \alpha^{*}\right) \mathrm{Y}^{*} \mathrm{eP} \mathrm{P}^{*}\right)\right] /\left[\left(1-\mathrm{c}(1-\quad \tau)\left(1-\alpha^{*} \beta\right)-\quad \mathrm{v}^{\prime}\left(1+\quad \mathrm{v}^{\prime \prime} \alpha^{*} \beta\right) \quad-\gamma+\mathrm{j}\left(1-\alpha^{*} \beta\right) \quad-\right.\right.
$$
$\left.\mathrm{xx} \alpha *^{2} \beta\right] \mathrm{Y}$

The numerator's expression indicates that from the export side the price level will be raised and this is a new insight obtained here, however, in a broader model the nominal exchange rate will be endogenous and one cannot rule out that there will be a nominal appreciation of the currency in the presence of foreign investors. Interestingly, BLANCHARD/MATSCHKE (2014) have presented empirical evidence on US multinational companies impact on host 
countries' US market access; obviously the presence of US affiliates abroad creates back home intensive lobbying for getting better access to the US market.

The effect of foreign investment on the price level concerns the adjustment speed on the one hand, on the other hand the numerator expression of P\# is affected and there are three terms in the numerator of the steady state equation:

- a negative consumption effect which dampens P\#

- a positive investment effect which raises P\#

- a positive import effect which dampens P\#

Let us consider the combined effects in the denominator:

$$
\mathrm{c}(1-\tau) \alpha^{*} \beta-\mathrm{v}^{\prime} \mathrm{v}^{\prime} \alpha^{*} \beta+\mathrm{jj}{ }^{*} \alpha^{*}-\mathrm{j} \alpha^{*} \beta-\mathrm{jj}{ }^{\prime} \beta \alpha *^{2}=\alpha^{*}\left(\mathrm{c}(1-\tau) \beta+\mathrm{jj} " \mathrm{j}\left(\beta+\mathrm{j} ” \alpha^{*}\right)-\right.
$$
v'v'B)

This expression exceeds zero and thus will reduce the steady state price level P\# if

$$
c(1-\tau)>v^{\prime} v+j\left(1+j{ }^{\prime} \beta\left(\alpha^{*}-1\right)\right)
$$

Government has an impact on this condition through the income tax rate. The impact of economic globalization as summarized by the paramaters $v, j,, j$ and $\alpha^{*}$ is ambiguous. To the extent that globalization should reduce the income tax rate, the probability that the sign $>$ will hold is reinforced. If the second right-hand term is close to zero and the the reinvestment effect of FDI inflows (v) is relatively small, globalization will dampen the price level and this naturally implies a nominal appreciation for the case of a small open economy. Foreign GDP has a positive impact on $\mathrm{P} \#$ through exports as have $\mathrm{P}^{*}$ and the nominal exchange rate. However, the arbitrage equation $\mathrm{P}=\mathrm{eP}^{*}$ implies that for a given foreign price level a decline of $\mathrm{P}$ will go along with a fall of the nominal exchange rate (in price notation).

Finally, let us look at two-way foreign direct investment. Thus the home economy is not only a host country of FDI, but it also has outward FDI, and outward FDI are assumed to generate better access of exporters to Country II, so that we have to consider the following definitions ( $\alpha$ is the share of the foreign capital stock $\mathrm{K}^{*}$ owned by investors from Country I, $\beta^{*}$ is the share of capital income in foreign GDP):

$$
Z=\left(1-\alpha^{*} \beta\right) Y+\alpha \beta^{*} q^{*} Y^{*}
$$

$$
\mathrm{Z}^{*}=\mathrm{Y}^{*}\left(1-\alpha \beta^{*}\right)+\alpha * \beta Y / \mathrm{q}^{*}
$$

The consumption function is given by 


$$
C=c(1-\tau)\left[\left(1-\alpha^{*} \beta\right) Y+\alpha \beta^{*} q^{*} Y^{*}\right]+c^{\prime} M / P
$$

The price adjustment function is given under the additional assumptions that the adjustment speed is influenced by both $\alpha^{*}$ and $\alpha$ (see the parameter $\psi$ ) and that supply effective supply can be written as $\sigma \mathrm{Y}$ where $\sigma$ is capacity utilization which depends on $\alpha^{*}$. Here, the idea is that the presence of foreign investors reinforce the quality of company governance so that $\sigma$ is raised, namely on the basis of the formula $\sigma=\sigma^{\prime}\left(1+\sigma^{\prime \prime} \alpha^{*}\right)$ where $\sigma^{\prime \prime}$ is a positive parameter and $\sigma^{\prime}$ (in the interval 0,1 ) is the average capacity utilization typical for an economy without FDI inflows. Hence we can write

$$
\mathrm{dP} / \mathrm{dt}=\lambda\left(1+\lambda{ }^{\prime \prime} \alpha^{*}+\psi \alpha\right)\left(\mathrm{Y}^{\mathrm{d}}-\sigma^{\prime}\left(1+\sigma^{\prime \prime} \alpha^{*}\right) \mathrm{Y}\right)=\lambda\left(1+\lambda{ }^{\prime \prime} \alpha^{*}+\psi \alpha\right) \mathrm{P}\left[\mathrm{c}(1-\tau)\left(1-\alpha^{*} \beta\right) \mathrm{Y}+\right.
$$$$
\mathrm{c}^{\prime} \mathrm{M} / \mathrm{P}+\mathrm{v}^{\prime}\left(1+\mathrm{v}^{\prime \prime} \alpha^{*} \beta\right) \mathrm{Y}+\gamma \mathrm{Y}+\mathrm{x}\left(1+\mathrm{x}^{\prime} \alpha^{*}\right)\left(\mathrm{Y}^{*}\left(1-\alpha \beta^{*}\right) \mathrm{e} \mathrm{P}^{*} / \mathrm{P}+\alpha^{*} \beta \mathrm{Y}\right)-\mathrm{j}\left(\left(1-\alpha^{*} \beta\right) \mathrm{Y}+\right.
$$
$\left.\left.\alpha \beta^{*} \mathrm{Y}^{*} \mathrm{eP} * / \mathrm{P}\right)-\sigma^{\prime}\left(1+\sigma^{\prime \prime} \alpha^{*}\right) \mathrm{Y}\right] \mathrm{P}$

Note that a potential source country market access effect of outward FDI flows will be ignored here for the sake of simplicity.

Thus, the steady state solution is given by

(31) P\#

$$
=\frac{\left[c^{\prime} M+x\left(1+x^{\prime} \alpha *\right) Y *(1-\alpha \beta *) e P *-j \alpha \beta * Y * e P *\right]}{Y\left[(c(1-\tau)-j)(1-\alpha * ß)+v^{\prime}\left(1+v^{\prime \prime} \alpha * ß\right)+\gamma+x\left(1+x^{\prime} \alpha *\right) \alpha * ß-\sigma^{\prime}\left(1+\sigma^{\prime \prime} \alpha *\right)\right]}
$$

The denominator has several terms with $\alpha$ and $\alpha^{*}$, respectively, that effectively stand for FDI globalization:

As regards the denominator it is assumed that $c(1-\tau)>j$. The impact of trade and FDI in the denominator are summarized in the remaining terms and the denominator is raised by these terms if $(c(1-\tau)-j)(1-\alpha * \beta)+v^{\prime}\left(1+v^{\prime \prime} \alpha * \beta\right)+\gamma+x\left(1+x^{\prime} \alpha *\right) \alpha * \beta>$ $\sigma^{\prime}\left(1+\sigma^{\prime \prime} \alpha *\right)$; if this is the case and the numerator is reduced by the combined impact of trade and FDI the steady state price level is reduced by economic globalization.

Note that $\sigma$ could be specified (with n, n' and n" representing positive parameters) as a sinus function $n+n$ ' $\sin (n$ "y') - with the parameters n, n' and n" determined by some exogenous dynamics - so that there will be output cycles in the steady state. With a sinus function adequately specified, there could be temporary inflation and temporary deflation over time, but the average inflation rate would be zero.

The approach presented here has not explicitly looked into the role of loans given by banks to companies. Such macrofinance aspects could be a future extension of research. 


\section{Policy Conclusions}

It has been shown that the quantity equation can be derived within a rather simple approach for both the case of a closed economy and an open economy. Not only for central it is important that one now can better understand the role of velocity and the various parameters identified here. Interestingly, fiscal policy - through the income tax rate - has an impact on $\mathrm{V}$ and this is a new critical insight. This suggests that there is an additional dimension for adequate cooperation between government setting the income tax rate and the central bank.

It should be noted that both inward and outward FDI have an important impact on both the adjustment speed of the price level (and inflation in the presence of inflationary expectations) and the steady state value of the price level (and inflation in the presence of inflationatory expectations. The approach presented allows in a fruitful way to get a better understanding of the links between globalization and price level dynamics and inflations dynamics, respectively.

The next step naturally will be to look into the empirical evidence on price level dynamics. It will be useful to make a distinction between three groups: Countries that are more or less only an FDI host country; or more or less only an FDI source country; and a third group where one finds both inward FDI and outward FDI. The effect of changes of the income tax rate on the price level also should be analyzed in an empirical context. 


\section{Appendix: Supply-side View on the Quantity Equation: Simple Monetary} Growth Model

It is assumed that real money balances $\left(\frac{M}{P}\right)$ are an input factor so that output is given by:
I.) $\quad \mathrm{Y}=\left(\frac{\mathrm{M}}{\mathrm{P}}\right)^{\beta^{\prime}} \mathrm{K}^{\beta}(\mathrm{AL})^{1-\beta-\beta^{\prime}}$
II.) $\quad S=s(1-\tau) Y$
III.) $\quad \mathrm{S}=\frac{\mathrm{dk}}{\mathrm{dt}}+\delta \mathrm{K} \rightarrow \mathrm{K}=\frac{\mathrm{s}}{\delta}-\frac{\frac{\mathrm{dK}}{\mathrm{dt}}}{\delta}$

If there is no net accumulation of capital, $\frac{\mathrm{dK} / \mathrm{dt}}{\delta}=0$, we obtain $\mathrm{K}=\mathrm{S} / \delta$, hence
IV.) $\quad \mathrm{Y}=\left(\frac{\mathrm{M}}{\mathrm{P}}\right)^{\beta^{\prime}}(\mathrm{K})^{\beta}(\mathrm{AL})^{1-\beta-\beta^{\prime}}$
V.) $\quad \mathrm{Y}=\left(\frac{\mathrm{M}}{\mathrm{P}}\right)^{\beta^{\prime}}\left(\frac{\mathrm{S}}{\delta}\right)^{\beta}(\mathrm{AL})^{1-\beta-\beta^{\prime}}$
VI. $\quad \mathrm{Y}=\left(\frac{\mathrm{M}}{\mathrm{P}}\right)^{\beta^{\prime}}\left(\frac{\mathrm{s}(1-\tau) \mathrm{Y}}{\delta}\right)^{\beta}(\mathrm{AL})^{1-\beta-\beta^{\prime}}$

Rearranging to have $y^{\prime}$ on the left-hand side gives with $\mathrm{m}^{\prime}:=\frac{\mathrm{M}}{(\mathrm{AL})}$
VII.) $\frac{\mathrm{Y}}{\mathrm{AL}}=\left(\frac{\frac{\mathrm{M}}{\mathrm{P}}}{\mathrm{AL}}\right)^{\beta^{\prime}}\left(\frac{\mathrm{s}(1-\tau) \mathrm{Y}}{\delta \mathrm{AL}}\right)^{\beta}$
VIII.) $\left(\mathrm{y}^{\prime}\right)^{1-\beta}=\left(\frac{\mathrm{m}^{\prime}}{\mathrm{P}}\right)^{\beta^{\prime}}\left(\frac{\mathrm{s}(1-\tau)}{\delta}\right)^{\beta}$
IX.) $\quad y^{\prime}=\left(\frac{m^{\prime}}{P}\right)^{\frac{\beta^{\prime}}{1-\beta}}\left(\frac{s(1-\tau)}{\delta}\right)^{\frac{\beta}{1-\beta}}$

Assuming $\tau$ to be rather small we can use the approximation $\ln (1-\tau) \approx-\tau$ :
X.) $\quad \ln y^{\prime}=\frac{\beta^{\prime}}{1-\beta}\left(\ln \mathrm{m}^{\prime}-\ln \mathrm{p}\right)+\frac{\beta}{1-\beta}(\ln \mathrm{s}-\tau-\ln \delta)$
XI.) $\quad \ln P=\ln \mathrm{m}^{\prime}-\frac{1-\beta}{\beta^{\prime}} \ln \mathrm{y}^{\prime}-\frac{\beta}{\beta^{\prime}}(\ln \mathrm{s}-\tau-\ln \delta)$

If $\beta^{\prime}=(1-\beta)$ we have $d \ln P / d \ln (M / P)=1$ which corresponds to the case of the traditional quantity equation. Equation XI shows that the relative money supply $\mathrm{m}^{\prime}$ positively effects the long run equilibrium price level while $\mathrm{y}^{\prime}$ has a negative impact on the price level; it 
is noteworthy that the income tax rate has a positive effect on the long run equilibrium price level. Compared to the approach based on excess demand the sign for the income tax rate is different so that the empirical analysis can help identifying whether the supply-side approach is relevant or the demand-side approach. It should be noted here that real money balances enter the production function as positive external effect of households' holding of money (WELFENS, 2011) so that the traditional money market equilibrium equation $M / P=$ $\left(h Y / h^{\prime} i\right)$ can be used $\left(\mathrm{h}>0, \mathrm{~h}^{\prime}>0\right)$; in the absence of inflation the nominal interest $\mathrm{i}$ would be equal to the real interest rate $r$.

For the special case that the output elasticity ( $\left.\beta^{\prime}\right)$ of real money balances is equal to $1-\beta$, from the monetary growth model developed in WELFENS (2011) we obtain the equation:

$$
\text { XII.) } \quad \mathrm{Y}=\left(\frac{\mathrm{M}}{\mathrm{P}}\right)\left(\frac{\mathrm{s}(1-\tau)}{\delta}\right)^{\frac{\beta}{1-\beta}}
$$

Hence we can define

$$
\text { XIII.) } \quad V^{\prime \prime}:=\left(\frac{s(1-\tau)}{\delta}\right)^{\frac{\beta}{1-\beta}}
$$

From this perspective velocity is now a parameter largely determined from the supply-side of the economy - see the parameter $B$-, the savings rate and the income tax rate. A rise of the income tax rate will raise the equilibrium price level. The long-term perspective obtained from the growth model thus is somewhat different from the demand side price adjustment equation presented earlier. Where is inflation? Or, how should we introduce it in a supply-side perspective. In a supply-side approach the easiest way to accommodate inflation and the respective inflationary expectations is to assume that the output elasticity of real money balances, and possibly also of capital, is directly reduced by the inflation rate $\pi$. A potential straightforward specification that takes into account the fact that inflation reduces the productivity of real money balances and real capital is thus

$$
\text { XIV.) } \quad \mathrm{Y}=\left(\frac{\mathrm{M}}{\mathrm{P}}\right)^{\beta^{\prime}-\varepsilon^{\prime} \pi} \mathrm{K}^{\beta-\varepsilon \pi}(\mathrm{AL})^{1-\beta-\beta^{\prime}}
$$

where $\varepsilon$ and $\varepsilon$ ' are positive parameters and could indeed represent the impact of the enhanced output variance and the associated inefficiencies in an inflationary environment. The assumption here is that the output elasticity of AL is not affected by inflation, specifically, it is not raised. The production function is no longer homogeneous. Without going into further detail - the inflation dynamics in a supply-side perspective is analyzed in a different contribution (WELFENS, 2014b) - one may point out that the supply-side perspective, in the context of a macroeconomic production function with real money balances as an input, also allows to derive a specific form of the quantity equation; and it could be interesting to consider the special case that $\mathrm{V}=\mathrm{V}$ ', One might also want to consider that the savings function is affected by inflation - to the extent that capital is a good hedge against the erosion 
of real wealth one may specify $S=s(1-\tau) Y+s^{\prime} \pi$ where $s^{\prime}$ is a positive parameter; this should be an adequate specification for modest inflation and it should be noted that the parameter s' summarizes both the effect of a pressure for raising savings - as inflation reduces real wealth through the inflation tax on real money balances - and the fact that inflation reinforces the wish of households to invest in physical capital, considered to be a rather good hedge against inflation. With rather high inflation rates, the parameter s' might become negative and a modified specification of the savings function could take this into account. 


\section{References:}

Blanchard, E.; Matschke, X. (2013), U.S. Multinationals and Preferential Market Access, Paper presented at the Ausschuß für Außenwirtschaftstheorie und Außenwirtschaftspoltik, University of Augsburg, May 30-31, 2014.

Fisher, I. (1911), The Purchasing Power of Money, New York: The MacMillian Company.

Friedman, M. (1968), Money, II, Quantity Theory, in: Sills, D. L. (Ed.), International Encyclopedia of the Social Sciences, Vol. 10, New York.

Friedman, M. (1971), Theoretical Framework for Monetary Analysis, National Bureau of Economic Research, New York.

Keynes, J.M. (1936), The General Theory of Employment, Interest and Money, Palgrave Macmillan, UK.

Piketty, T. (2014), Capitalism in the Twenty-First Century, Cambridge, MA: Belknap Press.

Welfens, P.J.J. (2011), Innovations in Macroeconomics, 3rd edition, Heidelberg and New York: Springer.

Welfens, P.J.J.; Perret, J. (2014), Information \& communication technology and true real GDP: economic analysis and findings for selected countries, p.5-27, International Economics and Iconomic Policy, Berlin Heidelberg: Springer. 